\title{
Income Inequality and Access to Housing: Evidence from China
}

\author{
Chuanchuan Zhang
}

\begin{abstract}
Economic theory suggests that income inequality predicts housing price and housing affordability for low-income households. Employing Chinese urban household survey data, this paper examines empirically the relationship between income inequality and access to housing for urban low-income households. The empirical results demonstrate that higher income inequality within cities is significantly related to a higher housing cost burden, a smaller per capita living space, and lower housing quality for low-income households. Further studies demonstrate that the negative impacts of income inequality could be moderated by product differentiation in housing markets, as a higher degree of differentiation in the size of housing units corresponds to a smaller effect of income inequality on housing affordability.
\end{abstract}

Key words: Income inequality; Access to housing; Low-income households; Urban China JEL Code: D31; O18; R21

\section{Author information:}

Chuanchuan Zhang, Assistant Professor, School of Economics, Central University of Finance and Economics; Email: ccz.zhang@gmail.com; Cell Phone: +86 18510777398; Mailing Address: No 39, South College Road, Haidian District, Beijing, 100081.

Research in this paper was supported by the National Social Science Foundation (Grant No. 14ZDB120), National Science Foundation (Grant No. 71503282) and "CUFE 121 Young Doctor Development Foundation" (Grant No.QBJ1417). I appreciate the helpful comments by Yaohui Zhao, two anonymous referees and the editors. All errors are my own. 


\section{Introduction}

China's real estate industry has been developing rapidly since the reform of the monetization of the housing distribution in $1998 .{ }^{(1)}$ As one consequence of the housing market reform, China's commercial housing price in urban areas increased dramatically during the period 2000-2012, particularly since 2004 (see Figure 1). Increases in urban housing prices far outpaced the income growth of urban households and thus makes housing unaffordable for many middle/low-income households. Households that live in small dwellings are now tagged by the Chinese news media as "city ants". The prevalence of "city ants", however, has not stopped the rise in housing prices. The deterioration in housing conditions experienced by low-income households and young people has given rise to complaints and social instability that will in turn hurt China's long-lasting development. How can housing prices continue soaring given many households cannot afford even a small house? Why can some households own more than one house while others live as "city ants"? This paper argues that rising income inequality is one important driving force in China's urban housing price increase relative to household income and causes housing affordability problems for low-income urban households.

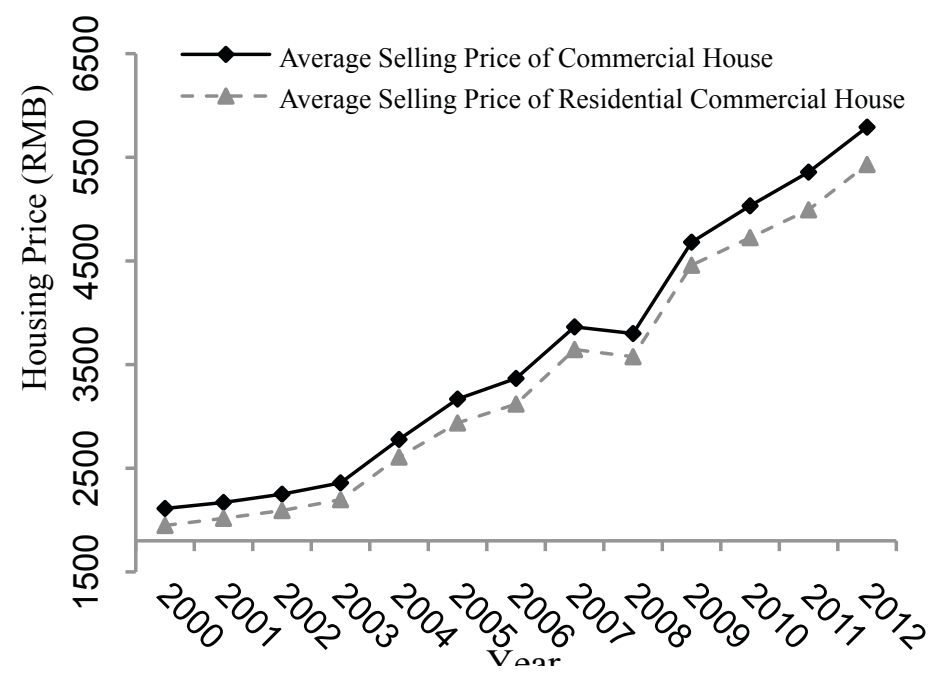

Figure 1 Average Housing Prices: 2000-2012

Source: Annual Statistic Data, 2013, NBS in China. (1) Monetization of housing distribution is the beginning of the third stage of China's urban housing reform.
China's urban housing reform initiated since 1978 was aimed to end the system of state provision of housing and
establish a housing market. During the first stage of 1978-1988, some small-scale housing reforms including
housing cost sharing among the state, enterprises and workers were piloted in several cities; during the second
stage of 1989-1997, state-owned housing units are allowed to sell to workers; and in 1998, in-kind housing
distribution system was entirely abolished and the old housing distribution system was transformed to a monetary
and market-oriented one. The second stage reform is usually called the privatization of housing, which has been
increasingly studied during recent years (for instance, see Wang, 2011 and Wang, 2012). 


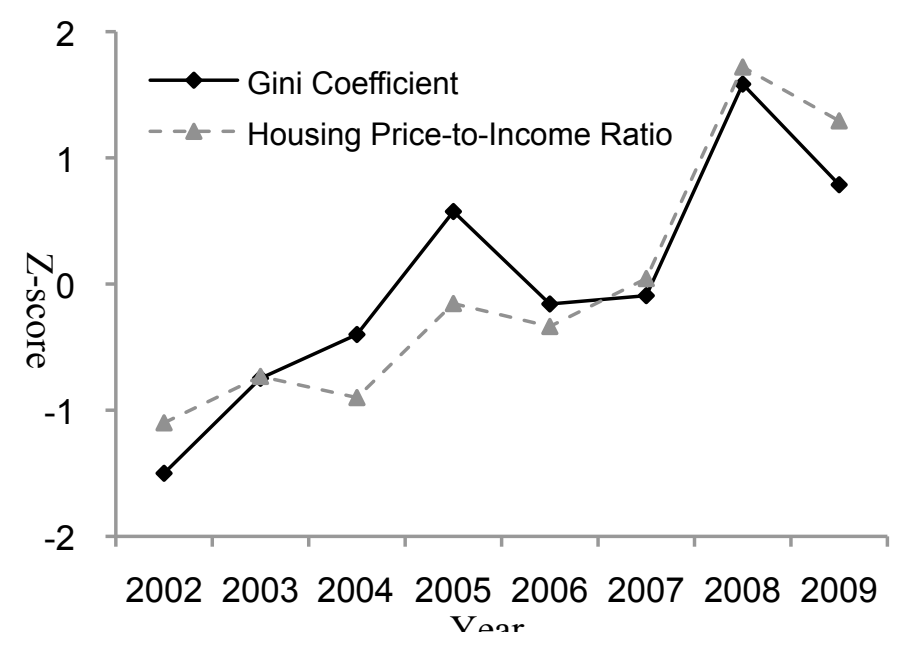

Figure 2 Trends in Income Inequality and Housing-Price-to-Income Ratio

Source: Chinese Urban Household Survey, 2002-2009.

Figure 2 presents the parallel trend of the urban housing-price-to-income ratio and Gini coefficient during the period 2002-2009, which demonstrates a clear correlation between housing prices relative to income and income inequality. Although the positive relationship between income inequality and housing-price-to-income ratio across time does not represent any causal effect, it does lead us to investigate whether the relative increase in income of wealthy households inflates urban housing prices and thus worsens the housing condition of the poor. Theoretically, it is easy to demonstrate that the increase in the income of wealthy households leads to higher housing prices and thus causes houses to be less affordable for low-income households in partial equilibrium. Similar to Matlack and Vigdor (2008), we can separate households into two groups: high-income households and low-income households, and depict the housing market as shown in Figure 3. Panel A presents the housing demand of high-income households and the change of demand induced by income growth, presuming that housing is a normal good. Panel C displays the corresponding change of housing demand in the entire market. Given that the housing supply is inelastic to some degree, an increase in housing demand will result in a higher equilibrium housing price faced by all households. As a result, low-income households are now facing higher prices and experiencing low housing consumption, as shown in Panel B. Allowing for production differentiation or household heterogeneity in the housing market may lead to different predictions. For instance, if there are housing units of two different sizes, say big and small, and wealthy 
households prefer large houses to small ones, the increase in income of wealthy households may decrease market demand for small houses and thus cause prices to decline, assuming the supply of housing is somewhat inelastic. However, as shown in Matlack and Vigdor (2008), even without product differentiation, the theoretical predictions could be ambiguous in general equilibrium. ${ }^{2}$

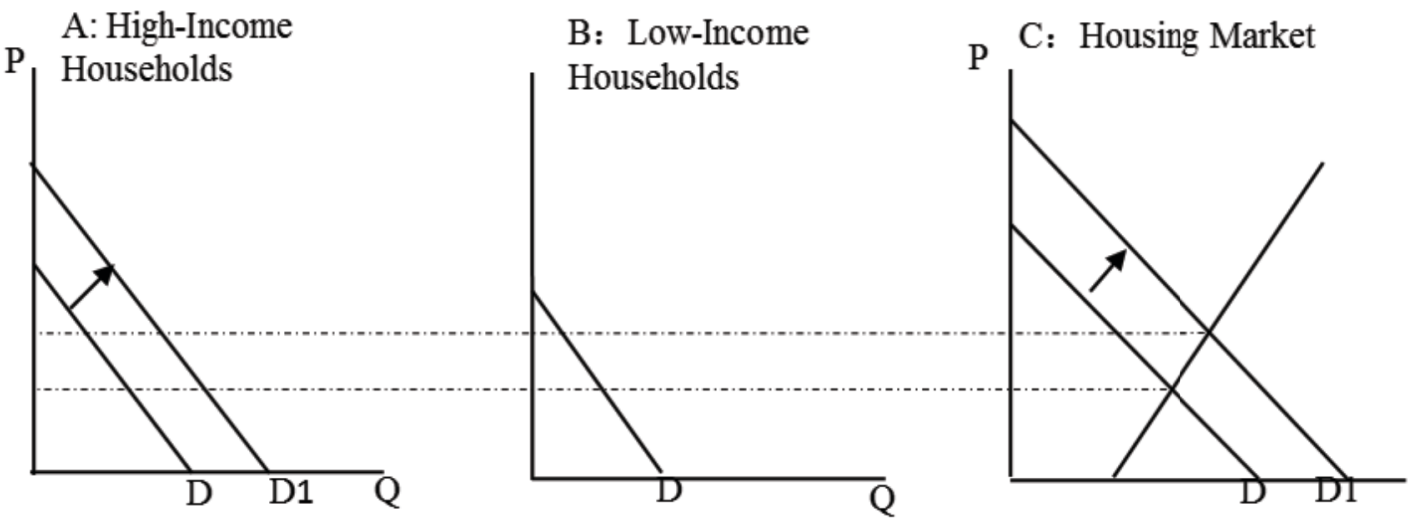

Figure 3 Housing Market

Note: Figure A presents the housing demand curve of high-income households and the change of demand (from D to D1) induced by income growth, Figure B presents the housing demand curves of low-income household, respectively, and Figure $\mathrm{C}$ presents the initial equilibrium and equilibrium after the increase of housing demand of high-income households in the local housing market.

Because of the theoretical ambiguity, whether income inequality causes worse housing conditions for low-income households in China is an empirical question. This paper aims to estimate empirically the relationship between income inequality and housing affordability for low-income urban households in China. Although it is not a novel idea that income inequality is associated with housing prices, there is little in the literature linking income inequality to access to housing for low-income households. Previous studies, including Rodda (1994), Quigley et al. (2001), and Quigley and Raphael (2004) have shown a positive relationship between income

\footnotetext{
(2) Matlack and Vigdor (2008) assume an asset A, say land, which can be transformed costlessly into housing. Both land and physical capital are employed in production, and a fraction of land is also utilized in consumption. Assuming only highly skilled (wealthy) individuals own land, the productivity increase of highly skilled individuals (and thus an increase in income inequality) could be offset by reductions in either the productivity of land or the productivity of physical capital. In the former case, the proportion of land used in consumption will increase and thus leads to an increase in housing consumption by low-skilled (poor) individuals.
} 
inequality and housing price, but only Matlack and Vigdor (2008) formally discussed the relationship between income inequality and housing affordability for low-income renters and empirically tested it utilizing US data. This study not only provides complementary empirical evidence from a developing country on the association between income inequality and housing outcomes but also has important policy implications in China. The Chinese Prime Minister, Keqiang Li, has called for the acceleration of urbanization at various meetings, focusing on the renovation of old districts and improvement of housing conditions for middle/low-income households. Moreover, income inequality has been rising for more than two decades in China, and there has continually been an academic focus on its socioeconomic impacts. This study, by linking income inequality and access to housing by low-income households in China, will provide new insights on the determinants of housing conditions for low-income households and the socioeconomic impacts of income inequality. The findings in this paper will be of interest to scholars and policy-makers concerned with either income inequality or urban housing issues.

Employing Chinese urban household survey (UHS) data from 2002 to 2009, this paper examines the relation between income inequality and access to housing for low-income households from three dimensions: the housing cost burden, quantity of housing consumption and housing quality. Empirical results demonstrate that income inequality within cities is positively related to housing cost burden and negatively related to per capita living space and housing quality. Considering product differentiation, the results suggest that the negative relationship between income inequality and housing cost burden for low-income households could be moderated by variations in the size of housing units.

The rest of this paper is structured as follows: section 2 describes the data and variables, section 3 presents the empirical analysis and results; and section 4 concludes.

\section{Data and Variables}

The dataset employed in this paper is from the Chinese urban household survey (UHS) released by the National Bureau of Statistics in China. The UHS is an annual survey targeting urban residents, and consists of comprehensive information on income, consumption, and wealth at both the individual and household level. The original survey covers all prefecture-level cities in 32 provinces (or province-level municipalities) in China, whereas this paper employs a subgroup 
of 186 cities in 16 provinces. ${ }^{3}$ Geographical distribution of these 186 cities is shown in Figure A1.

The paper is primarily concerned with low-income households, although access to housing of high-income households may be of interest to other studies. However, there is no uniform standard for defining "low-income households". The paper classifies households based on household disposable income per capita, and defines the bottom $20 \%$ within each city as low-income households for each year. ${ }^{(4)}$ As a sensitivity check, the bottom $30 \%$ households are also employed as low-income households. Income inequality within cities is measured using Gini coefficients, which are calculated based on household disposable income per capita. ${ }^{(5)}$ Access to housing is measured from three dimensions: the housing cost burden, quantity of housing consumption and housing quality, which were all often used in previous studies in measuring access to housing, for instance, Drever and Clark (2002), Edgar (2004) and Hulchanski (1997). The paper utilizes two measures for the housing cost burden: one is residual income and the other is rent-to-income ratio. These are the most prevalent measures of housing affordability in the literature (Stone, 2006). Residual income is calculated by subtracting housing rental expenses from household disposable income, while rent-to-income ratio is calculated as the ratio of housing rental expenses to household disposable income. It is straightforward to calculate the rental expense for renters, but for homeowners, we must utilize pseudo rental expenses in the sense of opportunity costs. For each household living in its own house, it is the self-reported UHS records rental price if the household rented out the house, which corresponds to the actual rental expense for the renters. This self-reported pseudo rental price is employed to calculate "rental expenses" for homeowners. The self-reported rental price measures the opportunity cost of housing for homeowners, and thus,

\footnotetext{
(3) Although the original survey covers all prefecture-level cities (approximately 330, varying slightly by years) in China, we only have access to this 16 provinces version. The same version is used in Meng et al. (2013), while another version of nine provinces is more widely used, for instance Li et al. (2012), Li et al. (2014). The 186 cities in our sample are clearly not a random draw from China's more than 300 cities, but the sample does cover a large number of Chinese cites, and most of them are located in China's middle and eastern regions where population density is high.

(4) We define low-income households by cities because we are treating each city as a local housing market and basically doing analysis within a partial equilibrium framework. Because we are using a panel data across several years, we define low-income households by each year to make sure that we are focusing on the impact of income inequality on vulnerable groups' housing situation.

(5) Theoretically, the increase of income inequality measured using Gini coefficient could be caused either by an increase of income in wealthy households or a decrease of income in low income households. In China, however, it cannot be the latter case as China is developing rapidly and almost everyone enjoys increasing income to certain extent. The increase of income inequality in China is mainly due to the more rapid increase of income in wealthy households, which can been seen from the change of income distribution during 2002 and 2009, as shown in Figure A2 in the appendix.
} 
it is a reasonable measure for housing affordability. ${ }^{(6}$ Essentially, all measures of housing affordability measure opportunity costs (Whitehead, 1991; Hancock, 1993). The quantity of housing consumption is measured by per capita living space. Based on what information we have from the UHS, housing quality is measured by a dummy indicating whether the house has indoor sanitary facilities. The dummy equals one if not, and zero for yes.

Table 1 Summary Statistics for Selected Variables

\begin{tabular}{|c|c|c|c|c|}
\hline \multirow[b]{2}{*}{ Variable } & \multicolumn{2}{|c|}{$\begin{array}{l}\text { Bottom } 20 \% \text { of } \\
\text { households }\end{array}$} & \multicolumn{2}{|c|}{$\begin{array}{l}\text { Bottom } 30 \% \text { of } \\
\text { households }\end{array}$} \\
\hline & Mean & Std. Dev. & Mean & Std. Dev. \\
\hline \multicolumn{5}{|l|}{ Household level variables } \\
\hline Residual income (RMB) & $10,995.910$ & $4,814.911$ & $13,198.540$ & $5,660.237$ \\
\hline Rent-to-income ratio & 0.178 & 0.157 & 0.162 & 0.147 \\
\hline Per capita living space $\left(\mathrm{m}^{2}\right)$ & 27.373 & 17.646 & 27.619 & 17.491 \\
\hline Lack of indoor sanitary ware $(=1$, yes $;=0$, no $)$ & 0.528 & 0.499 & 0.487 & 0.500 \\
\hline Household income (RMB) & $13,146.510$ & $4,768.146$ & $15,363.000$ & $5,814.900$ \\
\hline \multicolumn{5}{|l|}{ Characteristics of household head } \\
\hline Age & 49.164 & 12.023 & 49.077 & 12.037 \\
\hline Male $(=1$, male $;=0$, female $)$ & 0.711 & 0.453 & 0.720 & 0.449 \\
\hline Ethnicity: han $(=1$, yes; $=0$, no $)$ & 0.969 & 0.174 & 0.970 & 0.169 \\
\hline Local urban hukou (=1, yes; $=0$, no) & 0.970 & 0.171 & 0.972 & 0.165 \\
\hline Married (=1, yes; $=0$, no) & 0.864 & 0.343 & 0.885 & 0.319 \\
\hline Primary school (or below) $(=1$, yes; $=0$, no $)$ & 0.134 & 0.341 & 0.121 & 0.326 \\
\hline Middle school $(=1$, yes; $=0$, no $)$ & 0.414 & 0.493 & 0.392 & 0.488 \\
\hline High school $(=1$, yes; $=0$, no $)$ & 0.259 & 0.438 & 0.262 & 0.440 \\
\hline Vocational school $(=1$, yes; $=0$, no $)$ & 0.084 & 0.278 & 0.093 & 0.291 \\
\hline Three-year college $(=1$, yes; $=0$, no $)$ & 0.085 & 0.279 & 0.102 & 0.303 \\
\hline Four-year university $\quad$ or above $(=1$, yes $;=0$, no $)$ & 0.023 & 0.151 & 0.030 & 0.170 \\
\hline At work $(=1$, yes; $=0$, no $)$ & 0.662 & 0.473 & 0.672 & 0.469 \\
\hline Renter $(=1$, yes; $=0$, no $)$ & 0.171 & 0.377 & 0.156 & 0.363 \\
\hline \multicolumn{5}{|l|}{ City level variables } \\
\hline Gini coefficient & 0.308 & 0.043 & 0.305 & 0.043 \\
\hline Std. Dev. of house size & 33.996 & 15.850 & 33.916 & 15.833 \\
\hline
\end{tabular}

Source: Chinese Urban Household Survey, 2002-2009.

Note: Gini coefficient and Standard deviation of house size are calculated within each city for each year.

Characteristics of the household head are employed as controls in the regression analysis,

\footnotetext{
(6) It is acknowledged that self-reported rental prices can be an imprecise measure of housing costs if people have irrational estimates about the local housing market and thus on the potential price at which they can rent out their houses.
} 
which includes age, the squared term of age, ethnicity, hukou status, education level, marriage status, employment status and homeownership status. As noted in the introduction, the association between income inequality and access to housing could depend on product differentiation; thus, we calculate the standard deviation of the size of housing units within cities to measure the degree of product differentiation in the local housing market. Sample means and standard deviations of all related variables are reported in Table 1 . For the bottom $20 \%$ households, the residual income on average is approximately $11,000 \mathrm{RMB}$, but with a quite large standard deviation. The rent-to-income ratio is approximately $18 \%$. Per capita living space is 27 square meters. Approximately $53 \%$ of households have no indoor sanitary facilities. Household disposable income is $13,417 \mathrm{RMB}$, on average. The average age of the household head is 49 , with $71 \%$ of them being male, $97 \%$ being han ethnicity (i.e. not minorities), 97\% having a local urban hukou, $86.4 \%$ living with their spouse, and $66.2 \%$ working at the time of the survey. Only approximately $11 \%$ of the household heads hold a college degree. $17.1 \%$ of the households are renters. The city-level income Gini coefficient is approximately 0.31 , on average. For the bottom $30 \%$ of households, residual income and household disposable income are both approximately 2,200 RMB higher, on average, than the bottom $20 \%$ of households, per capita living space being approximately 0.25 square meters larger, rent-to-income ratio being approximately 1.6 percentage points lower, and average housing quality being better. There are no evident differences in the characteristics of household heads between the bottom $20 \%$ households and bottom $30 \%$ households, except for schooling and the homeownership status.

\section{Empirical Analysis and Results}

\subsection{Relationship between Income Inequality and Housing-Price-to-Income Ratio}

Before examining the impact of income inequality on the access to housing, we first demonstrate that housing prices relative to income, measured by the price-to-income ratio, are affected significantly by income inequality. Figure 1 in the introduction already demonstrated a close correlation between the Gini coefficient and housing-price-to-income ratio across time, so we now further examine the impact of income inequality on the housing-price-to-income ratio with the regression framework. We ran both OLS regressions and FE regressions on the following equation: 


$$
H P R_{j t}=\alpha+\beta G I N I_{j t}+\lambda X_{j t}+c_{j}+y_{t}+u_{j}
$$

where $H P R_{j t}$ is the housing-price-to-income ratio, defined as the ratio of median housing value to median household disposable income, in the $j$ th city and the $t$ th year. GINI $I_{j t}$ is the $j$ th city's income Gini coefficient in the th year, $X_{j t}$ is a set of control variables. $c_{j}$ and $y_{t}$ denote city fixed effects and year fixed effects, respectively. $u_{j t}$ is an error term.

The estimation results are shown in Table 2. A simple OLS regression without controls demonstrates that a one percentage point higher Gini is significantly associated with a 0.063 increase in the housing-price-to-income ratio. The OLS estimate decreases to 4.33 after adding control variables. The two-way fixed effect estimates with and without controls are smaller than the OLS estimates, but they still indicate a significant relationship between income inequality and the housing-price-to-income ratio. The FE estimate with controls demonstrates that a one percentage point higher Gini is significantly associated with a 0.025 increase in the housing-price-to-income ratio.

Table 2 Income Inequality and Housing Price-to-Income Ratio

\begin{tabular}{lcccc}
\hline & \multicolumn{4}{c}{ Housing Price-to-Income Ratio } \\
\cline { 2 - 5 } Independent variables & OLS & OLS & FE & FE \\
\hline \multirow{2}{*}{ Gini coefficient } & $6.296^{* * *}$ & $4.333^{* * *}$ & $2.077^{* * *}$ & $2.526^{* * *}$ \\
& $(0.803)$ & $(0.844)$ & $(0.639)$ & $(0.708)$ \\
& & & & No \\
Control variables & No & Yes & Yes & Yes \\
Year fixed effects & No & No & 1,365 & 1,237 \\
Observations & 1,365 & 1,237 & 0.318 & 0.344 \\
R-squared & 0.043 & 0.236 & 186 & 165 \\
Number of city & 186 & 165 &
\end{tabular}

Source: Chinese Urban Household Survey, 2002-2009.

Notes: Control variables include share of minorities, share of men, share of people older than 60 , share of people younger than 15 , share of college graduates, population density and GDP per capita. Robust standard errors in parentheses. ${ }^{* * *} \mathrm{p}<0.01, * * \mathrm{p}<0.05, * \mathrm{p}<0.1$.

\subsection{Relationship between Income Inequality and Access to Housing}

This section examines the relationship between income inequality and access to housing by estimating the following equation: 


$$
H_{i j t}=\alpha+\beta G I N I_{j t}+\lambda X_{i j t}+c_{j}+y_{t}+u_{i j}
$$

where $H_{i j t}$ is the dependent variable of interest, which can be the logarithm of residual income or rent-to-income ratio, the logarithm of per capita living space, a dummy variable indicating whether the house has indoor sanitary facilities. $G I N I_{j t}$ is the $j$ th city's income gini coefficient in the $t$ th year, $X_{i j t}$ is a set of control variables including household head's age, age squared, ethnicity (minority or not), hukou status, marriage status, education level, employment status and renter or not. $c_{j}$ and $y_{t}$ denote city fixed effects and year fixed effects, respectively. ${ }^{\circledR} u_{i j t}$ is an error term. Equation (2) is estimated by OLS, with city fixed effects and year fixed effects captured by including a set of dummy variables. Robust standard errors will always be reported allowing for clustering at the city-year level.

Table 3 presents the results of a regression specification examining the impact of income inequality on the housing cost burden measured by either the logarithm of residual income or rent-to-income ratio. As shown in column 2, with characteristics of household heads controlled, there is a significant relationship between income inequality and residual income. The point estimate suggests that a one standard deviation increase in the Gini coefficient $(0.043)$ decreases household's residual income by $3.8 \%$. Whether we include controls makes no large difference, suggesting the estimate is quite robust. Employing the sample of the bottom $30 \%$ households, we obtain consistent results but slightly larger point estimates as shown in column 3 and column 4 . Again, whether we include covariates basically makes no difference. These results are consistent with Matlack and Vigdor (2008), who employ data from the US. Column 5 to column 8 utilize the rent-to-income ratio to measure the housing cost burden. The results consistently suggest a statistically significant relationship between income inequality and the housing cost burden for low-income households. Whether we include household characteristics has almost no effect on the estimate of the effect of Gini coefficient, which gives us more confidence on the exogeneity of the Gini coefficient in this context.

\footnotetext{
(7) The UHS data does not have any information about the housing supply. Failing to control for the supply-side factors may cause endogenous bias if these factors are correlated with the Gini coefficient. We thus calculate real estate investment per capita as a proxy of housing supply utilizing information from China's City Statistics Yearbook and merge it with the UHS data. We reran all regressions controlling for real estate investment per capita and population density (which is also from the City Statistics Yearbook) but obtain quite similar results, although we lost a large number of observations due to missing values of these two variables. These results are available upon request.
} 
Table 3 Income Inequality and Housing Cost among Low-income Households

\begin{tabular}{|c|c|c|c|c|c|c|c|c|}
\hline \multirow[b]{3}{*}{ Independent variables } & \multicolumn{4}{|c|}{ Ln(Residual income) } & \multicolumn{4}{|c|}{ Rent-to-income ratio } \\
\hline & \multicolumn{2}{|c|}{ Bottom 20\% } & \multicolumn{2}{|c|}{ Bottom 30\% } & \multicolumn{2}{|c|}{ Bottom 20\% } & \multicolumn{2}{|c|}{ Bottom $30 \%$} \\
\hline & (1) & (2) & (3) & (4) & (1) & (2) & (3) & (4) \\
\hline \multirow[t]{2}{*}{ Gini coefficient } & $-0.871 * * *$ & $-0.888 * * *$ & $-0.973 * * *$ & $-0.960 * * *$ & $0.071 * * *$ & $0.073 * * *$ & $0.049 * *$ & $0.049 * *$ \\
\hline & $(0.151)$ & $(0.151)$ & $(0.129)$ & $(0.129)$ & $(0.026)$ & $(0.026)$ & $(0.020)$ & $(0.020)$ \\
\hline \multicolumn{9}{|l|}{ Characteristics of } \\
\hline \multicolumn{9}{|l|}{ household head } \\
\hline \multirow[t]{2}{*}{ Age } & & $-0.003 * *$ & & $-0.004 * * *$ & & $0.001 * *$ & & $0.001 * *$ \\
\hline & & $(0.001)$ & & $(0.001)$ & & $(0.000)$ & & $(0.000)$ \\
\hline \multirow[t]{2}{*}{ Age squared/100 } & & $0.006 * * *$ & & $0.007 * * *$ & & $-0.001 * * *$ & & $-0.001 * * *$ \\
\hline & & $(0.001)$ & & $(0.001)$ & & $(0.000)$ & & $(0.000)$ \\
\hline \multirow[t]{2}{*}{ Male } & & 0.004 & & -0.005 & & $-0.005 * *$ & & $-0.003 *$ \\
\hline & & $(0.006)$ & & $(0.005)$ & & $(0.002)$ & & $(0.001)$ \\
\hline \multirow[t]{2}{*}{ Ethnicity: han } & & $-0.031 * * *$ & & $-0.027 * * *$ & & $0.010 * *$ & & $0.010 * * *$ \\
\hline & & $(0.012)$ & & $(0.010)$ & & $(0.004)$ & & $(0.003)$ \\
\hline \multirow[t]{2}{*}{ Local urban hukou } & & $0.050 * * *$ & & $0.048 * * *$ & & $-0.030 * * *$ & & $-0.025 * * *$ \\
\hline & & $(0.017)$ & & $(0.014)$ & & $(0.005)$ & & $(0.004)$ \\
\hline \multirow[t]{2}{*}{ Married } & & $0.172 * * *$ & & $0.220 * * *$ & & $-0.022 * * *$ & & $-0.028 * * *$ \\
\hline & & $(0.010)$ & & $(0.009)$ & & $(0.003)$ & & $(0.002)$ \\
\hline \multirow[t]{2}{*}{ Middle school } & & $0.035 * * *$ & & $0.044 * * *$ & & 0.002 & & 0.000 \\
\hline & & $(0.008)$ & & $(0.007)$ & & $(0.002)$ & & $(0.002)$ \\
\hline \multirow[t]{2}{*}{ High school } & & $0.048 * * *$ & & $0.072 * * *$ & & $0.007 * * *$ & & 0.003 \\
\hline & & $(0.009)$ & & $(0.008)$ & & $(0.003)$ & & $(0.002)$ \\
\hline \multirow[t]{2}{*}{ Vocational school } & & $0.092 * * *$ & & $0.130 * * *$ & & 0.002 & & $-0.004 *$ \\
\hline & & $(0.011)$ & & $(0.009)$ & & $(0.003)$ & & $(0.002)$ \\
\hline \multirow[t]{2}{*}{ Three-year Colleges } & & $0.094 * * *$ & & $0.147 * * *$ & & $0.018 * * *$ & & $0.008 * * *$ \\
\hline & & $(0.011)$ & & $(0.009)$ & & $(0.003)$ & & $(0.003)$ \\
\hline \multirow{3}{*}{$\begin{array}{l}\text { Four-year } \\
\text { Universities }\end{array}$} & & $0066 * * *$ & & $0146 * * *$ & & & & \\
\hline & & & & & & $0.032 * * *$ & & $0.016 * * *$ \\
\hline & & $(0.023)$ & & $(0.016)$ & & $(0.006)$ & & $(0.004)$ \\
\hline \multirow[t]{2}{*}{ At work } & & $0.056 * * *$ & & $0.055 * * *$ & & $-0.008 * * *$ & & $-0.007 * * *$ \\
\hline & & $(0.006)$ & & $(0.006)$ & & $(0.002)$ & & $(0.002)$ \\
\hline \multirow[t]{2}{*}{ Renter } & & $0.023^{*}$ & & -0.007 & & $-0.014 * * *$ & & $-0.011 * * *$ \\
\hline & & $(0.012)$ & & $(0.011)$ & & $(0.004)$ & & $(0.003)$ \\
\hline City fixed effects & YES & YES & YES & YES & YES & YES & YES & YES \\
\hline Year fixed effects & YES & YES & YES & YES & YES & YES & YES & YES \\
\hline Observations & 39,338 & 39,338 & 60,548 & 60,548 & 34,723 & 34,723 & 51,542 & 51,542 \\
\hline R-squared & 0.213 & 0.232 & 0.213 & 0.241 & 0.298 & 0.304 & 0.297 & 0.303 \\
\hline
\end{tabular}

Source: Chinese Urban Household Survey, 2002-2009.

Notes: Please see Table 1 for detailed definitions of each variable. City fixed effects and year fixed effects are both captured by including a set of dummy variables. Robust standard errors clustered at the city-year level are in parentheses. $* * * \mathrm{p}<0.01, * *$ $\mathrm{p}<0.05, * \mathrm{p}<0.1$. 
The household characteristics are themselves significantly correlated. There is a nonlinear relationship between the household head's age and the housing cost burden, showing that the middle aged (30-40) households heads have the largest housing cost burden. Having a local urban hukou is related to a lower housing cost burden. Households of married couples have more residual income and a smaller rent-to-income ratio. Household head's education level and employment status are both related negatively to the housing cost burden. All of the estimates discussed above are reasonable. However, it is unclear why households headed by minorities have lower housing costs. Only $3 \%$ of the respondents are minorities and they may have some unobserved characteristics.

The estimation results from regressing on the quantity of housing consumption, i.e., per capita living space, are reported in Table 4 . The Gini coefficient is significantly correlated with the per capita living space of the bottom $20 \%$ of households, and the same for the bottom $30 \%$ of households. Controlling for the characteristics of household head does not change the estimates much. The estimate of the effect of Gini coefficient in column 2 suggests that a one standard deviation increase in the Gini coefficient is related to $1.5 \%$ less of per capita living space for the bottom $20 \%$ of households. The estimate using the sample of the bottom $30 \%$ of households is almost the same. Nevertheless, the association between income inequality and the housing consumption quantity is not strong although it is statistically significant. A one standard deviation increase in the Gini coefficient will decrease per capita living space by approximately 0.41 square meters at the sample mean level (that is, 27.3 square meters) for a four-person household. Household characteristics also have predictable effects on crowding: households headed by married men have smaller living spaces, as are households headed by less-educated persons. What is a little surprising is that households with household heads that are working are more crowded, which may reflect some unobservable composition of households. It is as expected that renters have significantly smaller living spaces than homeowners. In all, results reported in Table 4 are consistent with the theoretical predictions of the simple partial equilibrium model: income inequality leads to lower housing consumption quantities of low-income households. 
Table 4 Income Inequality and Crowding among Low-income Households

\begin{tabular}{|c|c|c|c|c|}
\hline \multirow[b]{3}{*}{ Independent variables } & \multicolumn{4}{|c|}{ Ln(Per capita living space) } \\
\hline & \multicolumn{2}{|c|}{ Bottom 20\% } & \multicolumn{2}{|c|}{ Bottom 30\% } \\
\hline & (1) & (2) & (3) & (4) \\
\hline \multirow[t]{2}{*}{ Gini coefficient } & $-0.526 * * *$ & $-0.353 * * *$ & $-0.462 * * *$ & $-0.375 * * *$ \\
\hline & $(0.094)$ & $(0.080)$ & $(0.077)$ & $(0.068)$ \\
\hline \multicolumn{5}{|c|}{ Characteristics of household head } \\
\hline \multirow[t]{2}{*}{ Age } & & $0.010 * * *$ & & $0.009 * * *$ \\
\hline & & $(0.001)$ & & $(0.001)$ \\
\hline \multirow[t]{2}{*}{ Age squared/100 } & & -0.002 & & -0.000 \\
\hline & & $(0.001)$ & & $(0.001)$ \\
\hline \multirow[t]{2}{*}{ Male } & & $-0.041 * * *$ & & $-0.036 * * *$ \\
\hline & & $(0.006)$ & & $(0.005)$ \\
\hline \multirow[t]{2}{*}{ Ethnicity: han } & & 0.019 & & 0.015 \\
\hline & & $(0.012)$ & & $(0.010)$ \\
\hline \multirow[t]{2}{*}{ Local urban hukou } & & $-0.071 * * *$ & & $-0.067 * * *$ \\
\hline & & $(0.016)$ & & $(0.014)$ \\
\hline \multirow[t]{2}{*}{ Married } & & $-0.336 * * *$ & & $-0.308 * * *$ \\
\hline & & $(0.009)$ & & $(0.009)$ \\
\hline \multirow[t]{2}{*}{ Middle school } & & $0.083 * * *$ & & $0.090 * * *$ \\
\hline & & $(0.008)$ & & $(0.007)$ \\
\hline \multirow[t]{2}{*}{ High school } & & $0.141 * * *$ & & $0.146^{* * *}$ \\
\hline & & $(0.008)$ & & $(0.007)$ \\
\hline \multirow[t]{2}{*}{ Vocational school } & & $0.191 * * *$ & & $0.189 * * *$ \\
\hline & & $(0.010)$ & & $(0.008)$ \\
\hline \multirow[t]{2}{*}{ Three-year Colleges } & & $0.269 * * *$ & & $0.276^{* * *}$ \\
\hline & & $(0.010)$ & & $(0.009)$ \\
\hline \multirow[t]{2}{*}{ Four-year Universities } & & $0.372 * * *$ & & $0.339 * * *$ \\
\hline & & $(0.014)$ & & $(0.012)$ \\
\hline \multirow[t]{2}{*}{ At work } & & $-0.024 * * *$ & & $-0.027 * * *$ \\
\hline & & $(0.006)$ & & $(0.005)$ \\
\hline \multirow[t]{2}{*}{ Renter } & & $-0.382 * * *$ & & $-0.383 * * *$ \\
\hline & & $(0.010)$ & & $(0.009)$ \\
\hline City fixed effects & YES & YES & YES & YES \\
\hline Year fixed effects & YES & YES & YES & YES \\
\hline Observations & 51,235 & 51,235 & 77,173 & 77,173 \\
\hline R-squared & 0.127 & 0.306 & 0.127 & 0.292 \\
\hline
\end{tabular}

Source: Chinese Urban Household Survey, 2002-2009.

Notes: Please see Table 1 for detailed definitions of each variable. City fixed effects and year fixed effects are both captured by including a set of dummy variables. Robust standard errors clustered at the city-year level are in parentheses. ${ }^{* * *} \mathrm{p}<0.01,{ }^{* *} \mathrm{p}<0.05,{ }^{*} \mathrm{p}<0.1$. 
Table 5 Income Inequality and Housing Quality among Low-income Households

\begin{tabular}{|c|c|c|c|c|}
\hline \multirow[b]{3}{*}{ Independent variables } & \multicolumn{4}{|c|}{ Lack of indoor sanitary facilities } \\
\hline & \multicolumn{2}{|c|}{ Bottom 20\% } & \multicolumn{2}{|c|}{ Bottom 30\% } \\
\hline & (1) & $(2)$ & (3) & (4) \\
\hline \multirow[t]{2}{*}{ Gini coefficient } & $0.117 *$ & $0.115^{*}$ & $0.162 * * *$ & $0.112 * *$ \\
\hline & $(0.069)$ & $(0.067)$ & $(0.057)$ & $(0.055)$ \\
\hline \multicolumn{5}{|c|}{ Characteristics of household head } \\
\hline \multirow[t]{2}{*}{ Age } & & $-0.003 * *$ & & $-0.005 * * *$ \\
\hline & & $(0.001)$ & & $(0.001)$ \\
\hline \multirow[t]{2}{*}{ Age squared/100 } & & $0.003 * * *$ & & $0.005 * * *$ \\
\hline & & $(0.001)$ & & $(0.001)$ \\
\hline \multirow[t]{2}{*}{ Male } & & $0.018 * * *$ & & $0.020 * * *$ \\
\hline & & $(0.005)$ & & $(0.004)$ \\
\hline \multirow[t]{2}{*}{ Ethnicity: han } & & -0.011 & & -0.001 \\
\hline & & $(0.012)$ & & $(0.010)$ \\
\hline \multirow[t]{2}{*}{ Local urban hukou } & & -0.015 & & $-0.018^{*}$ \\
\hline & & $(0.011)$ & & $(0.009)$ \\
\hline \multirow[t]{2}{*}{ Married } & & -0.005 & & $-0.021 * * *$ \\
\hline & & $(0.006)$ & & $(0.005)$ \\
\hline \multirow[t]{2}{*}{ Middle school } & & $-0.061 * * *$ & & $-0.054 * * *$ \\
\hline & & $(0.006)$ & & $(0.005)$ \\
\hline \multirow[t]{2}{*}{ High school } & & $-0.122 * * *$ & & $-0.118 * * *$ \\
\hline & & $(0.007)$ & & $(0.006)$ \\
\hline \multirow[t]{2}{*}{ Vocational school } & & $-0.150 * * *$ & & $-0.149 * * *$ \\
\hline & & $(0.009)$ & & $(0.007)$ \\
\hline \multirow[t]{2}{*}{ Three-year Colleges } & & $-0.179 * * *$ & & $-0.184 * * *$ \\
\hline & & $(0.009)$ & & $(0.007)$ \\
\hline \multirow[t]{2}{*}{ Four-year Universities } & & $-0.240 * * *$ & & $-0.222 * * *$ \\
\hline & & $(0.014)$ & & $(0.010)$ \\
\hline \multirow[t]{2}{*}{ At work } & & $-0.012 * *$ & & $-0.010 * *$ \\
\hline & & $(0.006)$ & & $(0.005)$ \\
\hline \multirow[t]{2}{*}{ Renter } & & $0.241 * * *$ & & $0.253 * * *$ \\
\hline & & $(0.005)$ & & $(0.004)$ \\
\hline City fixed effects & YES & YES & YES & YES \\
\hline Year fixed effects & YES & YES & YES & YES \\
\hline Observations & 51,917 & 51,917 & 77,933 & 77,933 \\
\hline R-squared & 0.219 & 0.266 & 0.212 & 0.261 \\
\hline
\end{tabular}

Source: Chinese Urban Household Survey, 2002-2009.

Notes: Please see Table 1 for detailed definitions of each variable. City fixed effects and year fixed effects are both captured by including a set of dummy variables. Robust standard errors clustered at the city-year level are in parentheses. ${ }^{* * *} \mathrm{p}<0.01,{ }^{*} \mathrm{p}<0.05, * \mathrm{p}<0.1$. 
The estimation results from regressing on the housing quality measured by whether having indoor sanitary facilities are reported in Table 5. As the results demonstrate in the first row, income inequality is statistically significantly correlated with access to indoor sanitary facilities, with the likelihood of having indoor sanitary facilities decrease with the rise of income inequality. Point estimates whether including household characteristics as controls are similar, which suggests the estimates are robust. However, it should be noted that the estimated effect of income inequality on access to indoor sanitary facilities is not economically significant. A one standard deviation increase in the Gini coefficient is only related to an approximately $0.5 \%$ lower chance of having indoor sanitary facilities among the bottom $20 \%$ of low-income households, which is modest. The estimated effect for the bottom $30 \%$ of households is similar, which still has no large economic significance.

In conclusion, throughout Tables 3 to 5 , the estimate results indicate a statistically significant relationship between income inequality and the access to housing for low-income households. In particular, a rise in income inequality predicts a higher housing cost burden, lower housing consumption in quantity and lower housing quality for low-income households. This empirical evidence supports the theoretical prediction of the simple partial equilibrium model discussed in the introduction, and are also consistent with what Matlack and Vigdor (2008) found employing US data.

People may also wonder what the impacts of income inequality on wealthy households' housing outcomes are. Because we have argued that increases in wealthy households' income raise housing prices, and thus lead to worse housing outcomes for the low-income households, we are not expecting to see negative impacts of income inequality on wealthy households' housing outcomes. As a comparison, we examine the relationship between income inequality and housing outcomes among the top $10 \%$ high-income households. As shown in Table 6, income inequality increases wealthy households' residual income, decreases the rent-to-income ratio, increases living space per capita, and decreases the likelihood of living in low-quality houses. 


\begin{tabular}{lllll}
\hline & $\begin{array}{l}\text { Ln(Residual } \\
\text { income) }\end{array}$ & $\begin{array}{l}\text { Rent-to-income } \\
\text { ratio }\end{array}$ & $\begin{array}{l}\text { Ln(Living } \\
\text { space PC) }\end{array}$ & $\begin{array}{l}\text { Lack of } \\
\text { indoor } \\
\text { sanitary } \\
\text { facilities }\end{array}$ \\
\cline { 2 - 5 } Independent variables & $(1)$ & $(2)$ & $(3)$ & $(4)$ \\
\hline Gini coefficient & $0.438^{* * *}$ & $-0.072^{* *}$ & $0.931^{* * *}$ & $-0.324^{* * *}$ \\
& $(0.121)$ & $(0.032)$ & $(0.132)$ & $(0.077)$ \\
Characteristics of household head & YES & YES & YES & YES \\
City fixed effects & YES & YES & YES & YES \\
Year fixed effects & YES & YES & YES & YES \\
Observations & 20,557 & 9,581 & 31,047 & 31,306 \\
R-squared & 0.590 & 0.400 & 0.251 & 0.273 \\
\hline
\end{tabular}

Source: Chinese Urban Household Survey, 2002-2009.

Notes: Model specifications are the same as those in Table 3, Table 4 and Table 5. Characteristics of household head include age, age squared, gender, ethnicity, hukou status, marital status, education level, working status and home ownership. Please see Table 1 for detailed definitions of these variables. City fixed effects and year fixed effects are both captured by including a set of dummy variables. Robust standard errors clustered at the city-year level are in parentheses. ${ }^{* * *} \mathrm{p}<0.01,{ }^{*} * \mathrm{p}<0.05,{ }^{*} \mathrm{p}<0.1$.

\subsection{Income Inequality and Access to Housing with Product Differentiation}

As the paper has discussed in the introduction, the theoretical prediction on the relationship between income inequality and the access to housing for low-income households could be ambiguous with product differentiation in a partial equilibrium model. Theoretically, production differentiation may mitigate the impact of income inequality on housing affordability for the low-income households. To test whether there is a moderating effect of product differentiation, the paper now includes an interaction term between income inequality and the degree of production differentiation measured by the standard deviation of the size of housing units in Equation (2). Specifically, we estimate the following equation:

$$
\begin{aligned}
& H_{i j t}=\alpha_{0}+\alpha_{1} G I N I_{j t}+\alpha_{2} \operatorname{StDevH}_{j t}+\alpha_{3}\left(\operatorname{GINI}_{j t}-\overline{G I N} \hat{h}_{t}{ }^{*}\left(\operatorname{StDevH} S_{t}-\overline{S t D e v H}\right)_{t}\right. \\
& +\alpha_{4} X_{i j t}+c_{j}+y_{t}+u_{i j t}
\end{aligned}
$$

where $S t D e v H S_{j t}$ is the standard deviation of the size of housing units in city $j$ in year $t$. We subtract sample means of $G I N I_{j t}$ and $S t D e v H S_{j t}$ from them to reparameterize the model so that the coefficients on the original variables have an interesting meaning. All other variables are the same as those in Equation (2). 


\begin{tabular}{|c|c|c|c|c|}
\hline & $\begin{array}{l}\text { Ln(Residual } \\
\text { income) }\end{array}$ & $\begin{array}{l}\text { Rent-to-income } \\
\text { ratio }\end{array}$ & $\begin{array}{l}\text { Ln(Living } \\
\text { space PC) }\end{array}$ & $\begin{array}{l}\text { Lack of } \\
\text { indoor } \\
\text { sanitary } \\
\text { facilities }\end{array}$ \\
\hline Independent variables & (1) & (2) & (3) & (4) \\
\hline \multicolumn{5}{|l|}{ Bottom $20 \%$ of households } \\
\hline Gini coefficient & $\begin{array}{l}-1.546 * * * \\
(0.334)\end{array}$ & $\begin{array}{l}0.360 * * * \\
(0.059)\end{array}$ & $\begin{array}{l}-0.358^{*} \\
(0.209)\end{array}$ & $\begin{array}{l}0.091 \\
(0.153)\end{array}$ \\
\hline $\begin{array}{l}\text { Demeaned Gini*Demeaned Std. D } \\
\text { size }\end{array}$ & $\begin{array}{l}0.020 * * \\
(0.008)\end{array}$ & $\begin{array}{l}-0.009 * * * \\
(0.002)\end{array}$ & $\begin{array}{l}-0.001 \\
(0.007)\end{array}$ & $\begin{array}{l}-0.001 \\
(0.004)\end{array}$ \\
\hline Std. Dev. of house size & $\begin{array}{l}-0.007 * * * \\
(0.002)\end{array}$ & $\begin{array}{l}0.003^{* * *} \\
(0.001)\end{array}$ & $\begin{array}{l}0.002 \\
(0.002)\end{array}$ & $\begin{array}{l}0.001 \\
(0.001)\end{array}$ \\
\hline Observations & 39,338 & 34,723 & 51,235 & 51,917 \\
\hline R-squared & 0.232 & 0.305 & 0.307 & 0.266 \\
\hline \multicolumn{5}{|l|}{ Bottom $30 \%$ of households } \\
\hline Gini coefficient & $\begin{array}{l}-1.280^{* * *} \\
(0.280)\end{array}$ & $\begin{array}{l}0.256^{* * *} \\
(0.045)\end{array}$ & $\begin{array}{l}-0.434 * * * \\
(0.159)\end{array}$ & $\begin{array}{l}-0.054 \\
(0.124)\end{array}$ \\
\hline $\begin{array}{l}\text { Demeaned Gini*Demeaned Std. D } \\
\text { size }\end{array}$ & $\begin{array}{l}0.010^{* *} \\
(0.005)\end{array}$ & $\begin{array}{l}-0.006^{* * *} \\
(0.001)\end{array}$ & $\begin{array}{l}0.001 \\
(0.005)\end{array}$ & $\begin{array}{l}0.005 \\
(0.003)\end{array}$ \\
\hline Std. Dev. of house size & $\begin{array}{l}-0.004 * \\
(0.002)\end{array}$ & $\begin{array}{l}0.002 * * * \\
(0.000)\end{array}$ & $\begin{array}{l}0.002 \\
(0.001)\end{array}$ & $\begin{array}{l}-0.001 \\
(0.001)\end{array}$ \\
\hline Observations & 60,548 & 51,542 & 77,173 & 77,933 \\
\hline R-squared & 0.241 & 0.304 & 0.293 & 0.261 \\
\hline Characteristics of household head & YES & YES & YES & YES \\
\hline City fixed effects & YES & YES & YES & YES \\
\hline Year fixed effects & YES & YES & YES & YES \\
\hline
\end{tabular}

Source: Chinese Urban Household Survey, 2002-2009.

Notes: Std. Dev. of house size is the standard deviation of house size caculated within each city for each year. Characteristics of household head include age, age squared, gender, ethnicity, hukou status, marital status, education level, working status and home ownership. Please see Table 1 for detailed definitions of these variables. City fixed effects and year fixed effects are both captured by including a set of dummy variables. Robust standard errors clustered at the city-year level are in parentheses. ${ }^{* * *} \mathrm{p}<0.01,{ }^{*} \mathrm{p}<0.05,{ }^{*} \mathrm{p}<0.1$.

Estimation results considering product differentiation are reported in Table 7. All regression specifications include household characteristics as covariates, coefficients of which are not reported to save space. At the sample mean level of product differentiation, there is still significantly negative correlation between income inequality and housing cost burden measured 
either by residual income or by rent-to-income ratio. More importantly, the estimates on the interaction terms in column 1 and column 2 demonstrate a moderating impact of product differentiation on the association between income inequality and housing affordability for low-income households. For housing crowding and housing quality, however, product differentiation has no moderating effect. At the sample mean level of product differentiation, there is also no statistically significant relationship between income inequality and housing quality. However, income inequality is always significantly related to smaller living space among low-income households. At the sample mean level of product differentiation, the estimated effects of income inequality on per capita living space are slightly larger than that reported in Table 4 .

In short, results reported in Table 7 suggest that the negative relationship between income inequality and the housing cost burden for low-income households still exist at the sample mean level of product differentiation. However, the product differentiation, measured by the standard deviation of housing area, does have significant moderating effects on the impact of income inequality on the housing cost burden for low-income households, which is consistent with the theoretical predictions.

\section{Conclusions}

Urban housing prices in China have been rising rapidly since 2004 and have made housing conditions for low-income households increasingly worse. This paper notes that an important driving force of the housing problems of the poor is income inequality. Employing urban household survey data from 2002 to 2009 , this paper empirically tests the relationship between income inequality and the access to housing for the low-income households in China. Empirical results demonstrate that income inequality predicts a higher housing cost burden, housing crowding, and lower housing quality of urban low-income households. This study also finds that production differentiation, measured by variations in the size of housing units in each city, has a moderating effect on the negative impact of income inequality on housing affordability for low-income households.

This study suggests that income inequality is one important factor that causes a rise in housing prices relative to income in China, which has been inappropriately ignored by previous 
studies that endeavored to explain housing prices in China. This study thus provides new insights into the determinants of housing prices in China. The empirically demonstrated negative impacts of rises in others' income on poor households' access to housing also provides new insights into both the determinants of housing conditions of the poor and the famous "trickle-down effect" theory. Empirical results in this paper make clear that letting others get rich first may not necessarily benefit the left-behind poor. In contrast, a rise in the income of wealthy individuals could increase product prices faced by the poor and thus makes the objective well-being of the poor worse. The policy implications are clear. In confronting rising income inequality in China, the Chinese government has obligations to take steps to provide housing security for urban low-income households. In the short term, adjusting the relative supply of housing units with different sizes would be helpful. For instance, the government could take actions to stimulate the supply of small sized houses, which are less attractive to wealthy people. In the long run, however, redistributive policies should be taken to fight against rising income inequality in China.

\section{References}

Aghion, Philippe. and Patrick Bolton. 1997. "A Theory of Trickle-Down Growth and Development." The Review of Economic Studies 64(2): 151-172.

Drever, Anita, and William Clark. 2002. "Gaining Access to Housing in Germany: The Foreign-minority Experience." Urban Studies, 39(13): 2439-2453.

Edgar, Bill. 2004. Policy Measures to Ensure Access to Decent Housing for Migrants and Ethnic Minorities. Joint Centre for Scottish Housing Research.

Hancock, Karen. 1993. “Can Pay? Won’t Pay? Or Economic Principles of Affordability.” Urban Studies 30(1): 127-145.

Hulchanski, David. 1997. "Immigrants and Access to Housing: How Welcome Are Newcomers to Canada.” In Metropolis Year II Conference. Retrieved November (Vol. 4, p. 2006).

Li, Hongbin, Lei Li, Binzhen Wu and Yanyan Xiong. 2013. "The End of Cheap Chinese 
Labor." The Journal of Economic Perspectives 26(4): 57-74.

Li, Hongbin, Xinzheng Shi and Binzhen Wu. 2013. "Retirement Consumption Puzzle in China." Available at SSRN: http://ssrn.com/abstract=2187005 or http://dx.doi.org/10.2139/ssrn.2187005.

Matlack, Janna and Jacob Vigdor. 2008. “Do Rising Tides Lift All Prices? Income Inequality and Housing Affordability.” Journal of Housing Economics 17(3): 212-224.

Meng, Xin, Kailing Shen, and Sen Xue. 2013. "Economic Reform, Education Expansion, and Earnings Inequality for Urban Males in China, 1988-2009." Journal of Comparative Economics 41(1): $227-244$

Quigley, John and Steven Raphael. 2004. "Is Housing Affordable? Why Isn't It More Affordable?" Journal of Economic Perspectives 18(1): 191-214.

Quigley, John, Steven Raphael and Eugene Smolensky. 2001. "Homeless in America, Homeless in California." Review of Economics and Statistics 83(1): 37-51.

Rodda, David. 1994. "Rich Man, Poor Renter: A Study of the Relation Between the Income Distribution and Low-cost Rental Housing.” UMI Dissertation Service, Ann Arbor, MI.

Stone, Michael. 2006. "A Housing Affordability Standard for the UK." Housing Studies 21(4), 453-476.

Wang, Shing-Yi. 2011. "State Misallocation and Housing Prices: Theory and Evidence from China.” American Economic Review 101(5): 2081-2107.

Wang, Shing-Yi. 2012. "Credit Constraints, Job Mobility, and Entrepreneurship: Evidence from a Property Reform in China." Review of Economics and Statistics 94(2): 532-551.

Whitehead, Christine. 1991. "From Need to Affordability: An Analysis of UK Housing Objectives." Urban Studies 28(6): 871-887 


\section{Appendix:}

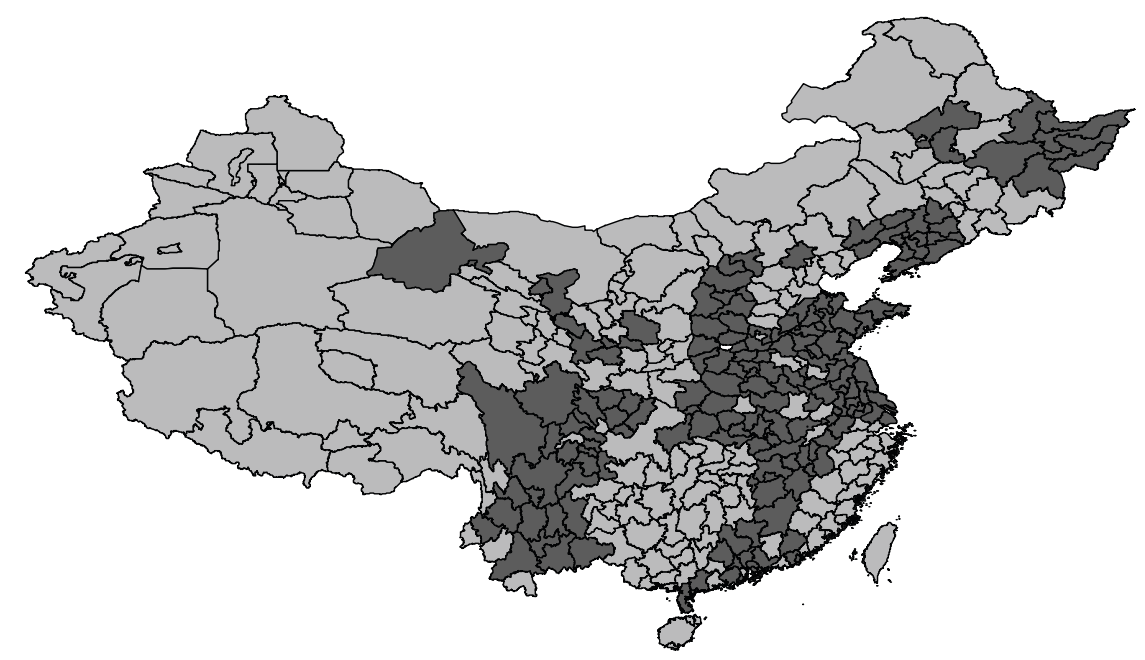

Figure A1 Geographical Distribution of Sample Cities

Note: Sample cities are colored in the darker grey.

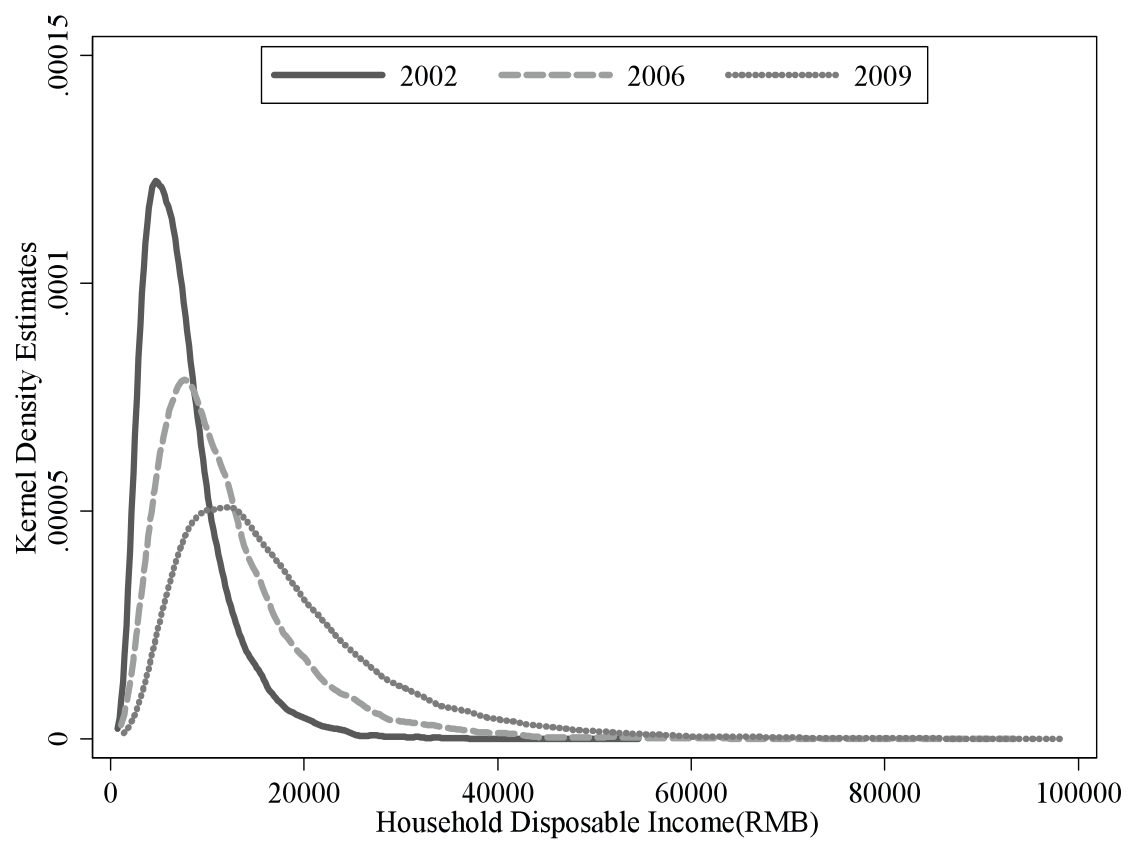

Figure A2 Changes of Income Distribution 
Source: Chinese Urban Household Survey, 2002, 2006, 2009. 